\title{
Quick Test with Tetrazolium Chloride on Coffee Seed Viability'
}

\author{
José R. Mondoñedo ${ }^{2}$
}

\section{INTRODUCTION}

The usual method employed to evaluate the germinative capacity of a batch of seeds is by actual germination under controlled conditions of moisture, temperature, light and media specific for the kind of seed being tested. Following this procedure with coffee seeds would require about 4 weeks; possibly longer with older seeds. Coffee seeds lose their viability very rapidly under normal atmospheric conditions. Results obtained from actual germination tests, therefore, are not representative of the germinative capacity at the time of completion of the test.

A quick viability test would make possible the rapid evaluation of coffee seeds being distributed or sold as planting materials. Those found unfit for planting still could be diverted to other uses.

\section{REVIEW OF LITERATURE}

Various methods of quick testing are being tried on different kinds of seeds. Of these, the use of water-soluble, non-toxic but light-sensitive tetrazolium chloride as an indicator of seed viability has shown great promise. Colbry et al. (1) $)^{8}$ cites Georg Lakon of Germany as the initiator of tetrazolium chloride (TZ) testing on seeds. Tetrazolium testing is based on the principle that the respiration process in living tissues releases hydrogen which combines with the colorless test solution producing an insoluble red pigment. Matson et al. (4) illustrates the reaction as follows:

$$
\begin{gathered}
2,3,5 \text { triphenyl tetrazolium chloride }+\frac{2 \mathrm{H}+2 \mathrm{e}}{\text { enzyme action }} \\
\text { triphenyl formazan (red) }+ \text { hydrochloric acid }
\end{gathered}
$$

Strong healthy tissues develop a coat of carmine red stain, weak tissues present a mottled or pink stain and dead tissues exhibit no color change.

Procedures have been developed in the use of tetrazolium salts for evaluating the germinative capacity of different kinds of seeds $(2, \Im, 6)$.

1 This study was conducted in the Department of Agronomy in cooperation with the Research Center of the University of Puerto Rico, Mayagüez Campus, Mayagüez, P.R.

2 Professor of Agronomy, Mayagüez Campus, University of Puerto Rico, Mayagüez, P.R.

Italic numbers in parentheses refer to Literature Cited, p. 376. 
Depending on the seed species being tested, the procedures varied in the method of preparing the seed for the test, the concentration of the test solution, the method of applying the test solution, and the period of time allowed in the solution. Rivas and Morillo (7) recommend the following procedure on coffee seed:

1. Seeds without parchment soaked in water for 24 hours.

2. Exposure of the radicle using thumb pressure over the seed after heating for 45 minutes at $40.5^{\circ} \mathrm{C}$.

3. Two drops of 2 percent TZ solution on the seed.

4. A pink to dark red coloration of embryo between 12 to 18 hours after treatment is considered a positive test.

These authors mentioned the difficulty of obtaining maximum contact of the embryo with the solution. Their report made no mention of the $\mathrm{pH}$ of the test solution used. This would vary depending on the concentration and kind of water or solvent used. Parker (5) reports that the $\mathrm{pH}$ of the $\mathrm{TZ}$ test solution affects the speed of the reaction in living tissues.

\section{MATERIALS AND METHODS}

Seeds of the Bourbon coffee crop of 1966 and 1967 were used in this study. Freshly harvested berries were hand-pulped, rinsed thoroughly, air-dried to about 40-percent moisture and stored in sealed containers at about $8^{\circ}$ to $10^{\circ} \mathrm{C}$. until needed.

\section{PREPARATION OF THE SEEDS FOR TESTING}

Seeds from the 1966 crop were removed of their parchment by hand, soaked in water for 1 to 24 hours, the silverskin rubbed off and kept moist until the next step. Dead seeds were obtained by boiling the fresh seeds in water for 5 minutes. Six lots of 10 seeds each were then prepared for treatment as follows:

Lot I. Fresh seeds intact.

Lot II. Excised embryo from fresh seeds.

Lot III. Fresh seeds cut longitudinally through the embryo slicing off a small portion of the cotyledon and radicle.

Lot IV. Boiled seeds intact.

Lot V. Excised embryo from boiled seeds.

Lot VI. Boiled seeds cut longitudinally through the embryo.

The prepared seeds were immersed overnight in 1 percent TZ solution and their reactions noted. This test was repeated for confirmation.

PREPARATION OF THE TEST SOLUTION AND DURATION OF IMMERSION

Using 2,3,5 triphenyl tetrazolium chloride and distilled water, concentrations of $0.1,0.5,1.5$ and 2.0 percent were prepared. Their $\mathrm{pH}$ read 
$3.7,3.2,2.9$ and 2.6 , respectively. To determine the effect of $\mathrm{pH}$ of the test solution on tissue reaction, $\mathrm{pH}$ levels of 9.0, 7.0, 5.0 and 3.0 were prepared for each test solution concentration using hydrochloric acid and sodium hydroxide. Being light sensitive, solutions were kept in colored bottles and stored in a refrigerator.

Fresh seeds from the 1966 crop prepared for treatment by sectioning through the embryo were fully immersed in sufficient amount of TZ test solution contained in Petri dishes, 50 seeds to each solution combination of $\mathrm{pH}$ and concentration. The Petri dishes with the seeds under treatment were kept in darkness at room temperature. At 2, 8, 16, 24 and 48 hours of immersion, 10 seed samples were taken from each Petri dish at random, rinsed and stored underwater at about $8^{\circ}$ to $10^{\circ} \mathrm{C}$. The treated seeds then were compared and rated as to color intensity reached using a color standard. This test was repeated for confirmation.

TZ TEST AND ACTUAL GERMINATTON TEST

Using the 0.5 percent TZ test solution neutralized to $\mathrm{pH} 7.0,100$ seeds from each of the following seed sources were prepared and tested:

Lot I. Fresh seeds from the 1966 crop.

Lot II. Seeds from the 19.66 crop, stored for 1 year.

Lot III. Fresh seeds from the 1967 crop.

Fresh seeds of the 1966 Bourbon coffee crop were tested soon after the seeds were prepared from freshly harvested berries. After storage of 1 year in sealed containers at $8^{\circ}$ to $10^{\circ} \mathrm{C}$., they were again tested together with a sample of freshly harvested 1967 crop. Speed of reaction was noted.

Actual germination tests were run concurrently with the TZ test, planting 100 seeds from each seed source in sand beds. Observations on percent germination, speed of germination and vigor of the seedlings were recorded. Seedling vigor was divided into two categories; strong and weak seedlings. These tests were run twice.

\section{RESULTS AND DISCUSSION}

The removal of the parchment by hand followed by soaking in water for 1 to 24 hours and removal of the silverskin were found necessary to facilitate the location of the embryo in the coffee seed. Soaking makes it easier to remove the silverskin and makes the endosperm transluscent so that from a dorsal view, the small white image of the embryo could be seen imbedded in the endosperm. For older and drier seeds, it was found convenient to soak them overnight to facilitate sectioning. Overnight soaking could possibly increase respiratory activities although this could not be seen clearly in terms of faster reaction to the test solution.

Excised whole embryo gave excellent results in time and intensity of 
reaction to the TZ test solution, presenting a very good picture of the condition of the entire embryo. The embryo, however, is intimately imbedded in the endosperm and taking it out or completely exposing it without injury is a difficult, time-consuming operation, thus impractical as a preparatory technique in regular testing procedures. On the other hand, sectioning through one side of the length of the embryo exposes the radicle, plumule and cotyledons to the test solution with a minimum of injury to the embryo. The embryo of fresh healthy seeds exhibited a uniform deep red color all over its surface after about 16 hours of treatment.

The endosperm in unsectioned seeds reacted slowly and superficially to the test solution. The test solution never quite reached the embryo within the 2 days of immersion. Boiled seeds did not pick up any color at all, remaining white up to about 2 days of immersion after which time microbial activity started to color up tissues and solution. Macerated tissues do not stain well. The use of a very sharp cutting blade for sectioning the seed was found essential to the test.

Table 1 shows the effect of solution concentration and $\mathrm{pH}$ on the degree of reaction achieved at different lengths of immersion time. It can be seen from this table that TZ test solutions of 0.5 and 1.0 percent at $\mathrm{pH}$ levels of 5 to 7 gave the best results. With this concentration and $\mathrm{pH}$ range, readings as early as 8 hours may be considered sufficient although 16 hours would be preferable. The 2.0 percent solution, especially at lower $\mathrm{pH}$, proved too strong. At higher $\mathrm{pH}$ levels of the 2.0 percent solution, the seeds reacted fast enough but never did quite achieve the deep red stain. On the other hand, the 0.1 percent solution was rather weak, needing a full 24-hour immersion to get a good reaction.

Comparison between the TZ test and actual germination test are presented in table 2. It can be seen from this table that the TZ test gave higher figures for germinative capacity than actual germination. This, of course, was expected because other factors such as dormancy and enviro.1. mental conditions influence germination. These factors do not enter in TZ testing. On borderline cases, especially in older seeds where mottling and lighter colors appear in greater frequency, it becomes mor: difficult to evaluate TZ test results and equate them with actual ger nination percentage. It can also be noted that the reaction time was . unger for older than fresh seeds.

\section{SUMMARY AND CONCLUSIONS}

The germinative capacity of coffee seeds may be evaluated within 2 days by using the following procedure:

1. The parchment is removed from a representative sample of coffee seeds 
TABLE 1.-Effect of tetrazolium chloride concentration and $p H$ on degree of color reaction ${ }^{2}$ on coffee seeds at various immersion periods

\begin{tabular}{|c|c|c|c|c|c|}
\hline \multirow{2}{*}{$\mathrm{pH}$} & \multirow{2}{*}{$\underset{\text { (hours) }}{\text { Immersion time }}$} & \multicolumn{4}{|c|}{ Tetrazolium chloride concentration in percent } \\
\hline & & 0.1 & 0.5 & 1.0 & 2.0 \\
\hline 9 & $\begin{array}{r}2 \\
8 \\
16 \\
24 \\
48\end{array}$ & $\begin{array}{l}E \\
D \\
C \\
B \\
B\end{array}$ & $\begin{array}{l}\mathrm{D} \\
\mathrm{C} \\
\mathrm{B} \\
\mathrm{B} \\
\mathrm{A}\end{array}$ & $\begin{array}{l}\mathbf{D} \\
\mathbf{C} \\
\mathbf{B} \\
\mathbf{B} \\
\mathbf{A}\end{array}$ & $\begin{array}{l}\text { D } \\
\text { C } \\
\text { B } \\
\text { B } \\
\text { B }\end{array}$ \\
\hline 7 & $\begin{array}{r}2 \\
8 \\
16 \\
24 \\
48\end{array}$ & $\begin{array}{l}E \\
\text { D } \\
\text { C } \\
\text { B } \\
B\end{array}$ & $\begin{array}{l}\mathbf{D} \\
\mathbf{C} \\
\mathbf{B} \\
\mathbf{A} \\
\mathbf{A}\end{array}$ & $\begin{array}{l}\text { D } \\
\mathbf{C} \\
\mathbf{B} \\
\mathbf{A} \\
\mathbf{A}\end{array}$ & $\begin{array}{l}\text { D } \\
\text { C } \\
\text { B } \\
\text { B } \\
\text { A }\end{array}$ \\
\hline 5 & $\begin{array}{r}2 \\
8 \\
16 \\
24 \\
48\end{array}$ & $\begin{array}{l}\mathbf{E} \\
\mathbf{D} \\
\mathbf{C} \\
\mathbf{B} \\
\mathbf{B}\end{array}$ & $\begin{array}{l}\mathrm{D} \\
\mathrm{C} \\
\mathrm{B} \\
\mathrm{A} \\
\mathrm{A}\end{array}$ & $\begin{array}{l}\text { D } \\
\text { C } \\
\text { B } \\
\text { A } \\
\text { A }\end{array}$ & $\begin{array}{l}\text { D } \\
\text { C } \\
\text { B } \\
\text { B } \\
\text { B }\end{array}$ \\
\hline 3 & $\begin{array}{r}2 \\
8 \\
16 \\
24 \\
48\end{array}$ & $\begin{array}{l}\mathbf{E} \\
\mathrm{D} \\
\mathbf{C} \\
\mathbf{B} \\
\mathbf{B}\end{array}$ & $\begin{array}{l}E \\
D \\
C \\
B \\
B\end{array}$ & $\begin{array}{l}\mathbf{E} \\
\mathbf{D} \\
\mathrm{D} \\
\mathrm{C} \\
\mathrm{C}\end{array}$ & $\begin{array}{l}D \\
D \\
D \\
D \\
D\end{array}$ \\
\hline
\end{tabular}

I $A=$ Deep red; $B=$ Red; $C=$ Pink; $D=$ Light pink; $E=$ White.

TABLE 2.-Comparison between tetrazolium chloride test and actual germination test on coffee seeds

\begin{tabular}{|c|c|c|c|c|c|c|c|c|c|}
\hline \multirow{3}{*}{$\begin{array}{c}\text { Seed } \\
\text { source }\end{array}$} & \multicolumn{6}{|c|}{ Tetrazolium chloride test } & \multicolumn{3}{|c|}{ Germination test } \\
\hline & \multicolumn{3}{|c|}{ Reaction time } & \multicolumn{3}{|c|}{ Color reaction } & \multirow{2}{*}{ Strong } & \multirow{2}{*}{ Weak } & \multirow{2}{*}{ Dead } \\
\hline & $\underset{\text { reed }}{\text { Deep }}$ & Red & Pink & Red & $\begin{array}{c}\text { Pink- } \\
\text { mottled }\end{array}$ & White & & & \\
\hline & Bours & Bours & Hours & Percent & Percent & Percent & Percent & Percent & Percent \\
\hline 1966 fresh & 18 & 12 & 3 & 100.0 & 0.0 & 0.0 & 99.5 & 0.5 & 0.0 \\
\hline 1966 stored & 24 & 18 & 6 & 58.0 & 21.5 & 20.5 & 30.5 & 24.0 & 45.5 \\
\hline 1967 fresh & 18 & 12 & 3 & 99.0 & 1.0 & 0.0 & 97.0 & 1.0 & 2.0 \\
\hline
\end{tabular}


and the seeds are soaked in water for an hour or more. Soaking for 24 hours is recommended for older and drier seeds.

2. The silverskin then is rubbed off, the seed rinsed, and kept in water ready for sectioning.

3. With a sharp blade, the seed is sectioned longitudinally through the embryo (slicing off a small portion of the cotyledons and radicle) which is imbedded in the endosperm but visible from the dorsal side.

4. The part with the larger section of the embryo is fully immersed for 16 to 24 hours in the TZ test solution ( 0.5 to 1.0 percent $2,3,5$ triphenyl tetrazolium chloride in distilled water, adjusted to $\mathrm{pH} 5$ to 7).

5. After immersion, the seed sections are rinsed and the embryo and endosperm examined carefully. Uniform red pigmentation on the embryo and endosperm indicates healthy viable seed. Pink or mottled coloration indicates weak seed of doubtful germinative capacity. White or no color change indicates dead seed.

6. Reading of results may be delayed several days by rinsing the treated seeds with water and storing them underwater at $8^{\circ}$ to $10^{\circ} \mathrm{C}$.

It is recommended that more tests be conducted to determine more accurately the relationship between TZ test results and actual germination tests, especially those borderline cases exhibiting pink or mottled coloration. An easier method of exposing the uninjured whole embryo to the test solution could help in these cases. It also may be worth looking into a much longer duration of soaking before sectioning as this affects speed of reaction to the test, especially on older and drier seeds.

\section{RESUMEN}

La capacidad germinativa de semillas de café podría evaluarse en 2 días mediante el siguiente procedimiento:

1. Se le quita el pergamino a una muestra representativa de semillas de café y se coloca en agua por lo menos 1 hora.

2. Se elimina la película plateada que cubre la semilla, se lava y se deja en agua lista para seccionarla.

3. Con una cuchilla bien afilada se corta la semilla longitudinalmente, atravesando el embrión (cortando una porción pequeña del cotiledón y la radicula), el cual se encuentra dentro del endosperma pero es visible desde el lado dorsal.

4. Se sumerge la sección más grande de la semilla en la solución TZ (0.5 a 1.0 porciento de $2,3,5$ cloruro de trifenil tetrazolio en agua destilada, ajustado a un $\mathrm{pH}$ de 5 a 7) por 16 a 24 horas.

5. Se lava la semilla después de la inmersión y se examinan el endosperma y el embrión cuidadosamente. Una pigmentación roja uniforme en el embrión y el endosperma indica que la semilla es viable y vigorosa. Una 
coloración rosada o moteada indica que la semilla es débil y de una capacidad germinativa dudosa. Las semillas muertas no cambian el color, permaneciendo blancas.

6. La lectura de los resultados podría ser pospuesta por varios días, lavando las semillas tratadas con agua y manteniéndolas en agua a una temperatura de $8^{\circ}$ a $10^{\circ} \mathrm{C}$.

Se recomienda que se hagan más pruebas para determinar con precisión la relación entre las pruebas TZ y la germinación real, especialmente en aquellos casos dudosos que exhiben colores rosado o moteado. Hace falta un método más sencillo o fácil de exponer el embrión entero en estos casos. Se podría dejar la semilla por más tiempo en agua antes de seccionarla y observar la rapidez de la reacción a la p ueba, especificamente en semillas más viejas y más secas.

\section{LITERATURE CITED}

1. Colbry, V. L., Swofford, T. F., and Moore, R. P., Test for germination in the laboratory, Seeds, USDA Yearbook of Agriculture, pp. 433-43, 1961.

2. Cottrel, H. J., Tetrazolium salt as a seed germination indicator, Ann. Appl. Biol. S5: 123-31, 1948.

3. Flemion, F., and Poole, H., Seed viability tests with tetrazolium, Cont, Boyce Thompson Institute 16 (4): 243-58, 1948.

4. Matson, A. M., Jensen, C. O., and Dutcher, R. A., Triphenyl tetrazolium chloride as a dye for vital tissues, Science 106: 294-95, 1947.

5. Parker, J., Some applications and limitations of tetrazolium chloride, Science 118: 77-9, 1953.

6. Porter, R. H., Durell, M., and Romm, H. J., The use of $2,3,5$ triphenyl tetrazolium chloride as a measure of seed germinatibility, Plant Physiol. 22: 149-59, 1947.

7. Rivas, A., and Morillo, A. R., Uso del tetrazolium en la determinación del poder germinativo de la semilla de café, Agron. Trop. 14 (1): 25-32, 1964. 